\title{
CYTOSKELETAL CHANGES IN NON-APOPTOTIC CELL DEATH
}

\author{
Emil Rudolf, Miroslav Červinka
}

Charles University in Prague, Faculty of Medicine in Hradec Králové, Department of Medical Biology and Genetics

\begin{abstract}
Summary: Dynamic morphology and cytoskeletal changes in Hep-2 cells exhibiting features of non-apoptotic cell death after treatment with zinc were studied using immunofluorescence microscopy and spectrofluorimetry. Among early morphological changes in treated cells was development of vacuolization, surface blebbing, relatively rapid cell detachment from substratum, cell shrinkage and, in some cases, appearance of membrane protrusions. Staining of microfilaments revealed rapid rearrangement and subsequent loss of F-actin accompanied by changes in the amount and localization of G-actin. The use of specific kinase and caspase inhibitors did not prevent surface blebbing as well as other morphological features in dying cells. Dying cells were only weakly positive for phosphatidyl serine and showed only a transient activation of caspase-9 with no signs of activation of caspase-3. These results suggest the existence of nonapoptotic cell death showing morphological features of both apoptosis and necrosis but, biochemically, resembling some other type of cell death.
\end{abstract}

Key words: Hep-2 cells; Non-apoptotic cell death; Morphology; Surface blebbing; Cytoskeleton; Caspases; Necrosis

\section{Introduction}

Established concept of cell death recognizes its two opposite forms - apoptosis and necrosis. Apoptosis or programmed cell death is characterized by distinct morphological and biochemical changes including cell membrane blebbing, nuclear condensation, specific DNA cleavage and cellular fragmentation into apoptotic bodies in the absence of inflammatory process. These characteristic apoptotic features depend on the activation of executionary enzymes - caspases by intrinsic or extrinsic ways and require energy in the form of ATP (2).

Necrosis, on the other hand, has been traditionally described as an accidental, passive form of cell death resulting from an insult leading to rapid ATP depletion. Morphologically, necrotic cells develop an extensive cytoplasmic vacuolization, organelle degradation and random nuclear dispersion. In addition, plasma membrane in thus dying cells rapidly collapses, leading to the release of cellular contents with resulting inflammation (3).

Recently, alternative forms of cell death have been reported in several experimental systems and named as programmed necrosis, autophagy, aponecrosis or necroptosis. The key features of these forms of cell demise are (A) simultaneous presence of markers of both apoptosis and necrosis or/and (B) execution of death program in the absence of caspases, i.e. caspase-independent cell death or (C) intracellular reversion of death program leading to a different phenotype of dying cells $(9,11)$.
While molecular mechanisms underlying the activation and execution of non-apoptotic and non-necrotic cell death are being intensively studied, morphological aspects of such dying cells, their variability and involvement of cytoskeleton and particular intracellular signaling pathways remain relatively underexplored. In our present study we investigated dynamic morphology and cytoskeletal changes in Hep-2 cells exhibiting features of non-apoptotic cell death after treatment with zinc $(\mathrm{Zn})$ by means of immunofluorescence microscopy and spectrofluorimetry. We found that $\mathrm{Zn}$ induced cell death was accompanied by development of vacuolization, surface blebbing, cell detachment and relatively variable changes of the nucleus as well as the cell body.

\section{Materials and methods}

\section{Chemicals}

Zinc sulfate; 4', ML-7, 6-diamidino-2-phenylindole (DAPI), phalloidin-TRITC, deoxyribonuclease I, Alexa Fluor-488 conjugate, z-VAD-fmk and Triton-X were purchased from Sigma-Aldrich (Prague, Czech Republic). Y27632 was from Calbiochem (Nottingham, UK). Annexin V-FITC was obtained from Bender MedSystems Diagnostics GmbH (Vienna, Austria). All other chemicals were of highest analytical grade.

\section{Cell line}

The continuous cell line Hep-2 (ECACC, No. 86030501 , Porton Down) was cultivated in a humidified 5\% 
$\mathrm{CO}_{2}$ atmosphere at $37^{\circ} \mathrm{C}$ in Dulbecco's modified Eagle's medium - DMEM (Gibco, Prague, Czech Republic) supplemented with $10 \%$ bovine serum (Gibco, Prague, Czech Republic), penicillin $\mathrm{G}(100 \mathrm{U} / \mathrm{ml})$ and streptomycin (100 $\mu \mathrm{g} / \mathrm{ml}$ ). Cells were seeded into 96-well plates (Nunclon, Roskilde, Denmark) or modified cytospin chambers (Hettich, Tuttlingen, Germany) treated with $\mathrm{Zn}$ or co treated with kinase inhibitors. Only mycoplasma-free cells were used for experiments.

\section{Morphology of cytoskeletal changes}

\section{Phase contrast}

Cultures at different treatment times were observed under an upright microscope Nikon Eclipse E 400 (Nikon Corporation, Kanagawa) and phase contrast images were taken by the digital color matrix camera COOL 1300 (VDS, Vosskühler, Germany).

\section{Fluorescence}

Cover slips with control and treated cultures were fixed with $4 \%$ formaldehyde and permeabilized with $1 \mathrm{ml}$ of $0.1 \%$ Triton X solution. The cells were then stained with TRITC conjugated phalloidin and Alexa 488 conjugated deoxyribonuclease I at concentration of $10 \mu \mathrm{g} / \mathrm{ml}$ for 30 minutes, post-labeled with DAPI and mounted into SlowFade ${ }^{\circledR}$ medium (Molecular Probes, inc. Eugene, U.S.A.). The localization and status of F-actin and G-actin were examined under the fluorescence microscope Nikon Eclipse E 400 (Nikon Corporation, Kanagawa, Japan) equipped with the digital camera COOL 1300 (VDS, Vosskühler, Germany). Photographs were taken using the software LUCIA DI image Analysis System LIM (Laboratory imaging Ltd., Prague, Czech Republic) and analyzed.

\section{F-actin and G-actin measurements}

Hep-2 cells (10,000 cells/well) were seeded into 96-well plates and allowed to grow overnight at $37^{\circ} \mathrm{C}$ and $5 \% \mathrm{CO}_{2}$. Next day, cultivation medium was replaced by medium supplemented with $300 \mu \mathrm{M} \mathrm{Zn}$ and its effect on F- and Gactin was evaluated after $1-8 \mathrm{~h}$ exposure. At each treatment interval, cells in corresponding wells were washed by $200 \mu 1$ PBS and subsequently fixed by $2 \%$ paraformadehyde ( 30 min, room temperature). After second washing with PBS and permeabilization $(200 \mu \mathrm{l} 0.1 \%$ Triton X-100, $5 \mathrm{~min}$, room temperature), $450 \mathrm{nM}$ TRITC-phalloidin and deoxyribonuclease i, Alexa Fluor-488 conjugate were added to each well. Staining was carried out for $30 \mathrm{~min}$ in darkness at room temperature. Finally, cells were washed twice with ion-free PBS and fluorescence of F- and G-actin was measured in a multiplate reader TECAN SpectraFluo Plus (TECAN Austria GmbH, Grödig, Austria) at 485/520 nm and $520 / 590 \mathrm{~nm}$ filter combinations, respectively.

Results were expressed as percentage of control after blank subtraction.

\section{Detection of cell death}

\section{Phosphatidyl serine translocation}

Cultures were twice rinsed with phosphate saline buffer, $1 \mathrm{ml}$ of Annexin-binding buffer with $20 \mu \mathrm{l}$ of Annexin VFITC (A) and $20 \mu$ of propidium iodide (PI) was added, and slides were left at dark for $15 \mathrm{~min}$. Next, labeling medium was aspirated and $1 \mathrm{ml}$ of Annexin-binding buffer was added for $1 \mathrm{~min}$. The buffer was aspirated and slides were mounted into SlowFade ${ }^{\circledR}$ medium (Molecular Probes, inc. Eugene, U.S.A.) and examined under a fluorescence microscope Nikon Eclipse E 400 (Nikon Corporation, Kanagawa) with the digital color matrix camera COOL 1300 (VDS, Vosskühler, Germany). Annexin positivity was evaluated by the software LUCIA DI image Analysis System LIM (Laboratory imaging Ltd., Prague, Czech Republic) in at least 1,000 cells per sample.

\section{Immunofluorescent staining of caspases}

Slides with treated and control cultures were fixed with $4 \%$ formaldehyde, rinsed three times with phosphate saline buffer with Triton X (PBS-T) and then exposed to skimmed milk for $30 \mathrm{~min}$ at RT. After this period, primary antibodies (polyclonal rabbit anti-human caspase-9, 1:100 - Santa Cruz Biotechnology inc, Santa Cruz, USA, polyclonal rabbit anti-human caspase-3, 1:50 - Dako, Glostrup, Denmark) were added to the cells and the samples were incubated for $60 \mathrm{~min}$ at $4^{\circ} \mathrm{C}$. The slides were then rinsed three times with PBS, secondary antibodies (IgG anti-mouse or anti-rabbit conjugated with Alexa 488 or Alexa 546, 1:400 - Molecular Probes, inc. Eugene, U.S.A.) were added, and the cells were incubated for $60 \mathrm{~min}$ at RT. The specimens were optionally post-labeled with DAPI, mounted into SlowFade ${ }^{\circledR}$ medium (Molecular Probes, inc. Eugene, U.S.A.) and examined under a fluorescence microscope Nikon Eclipse E 400 (Nikon Corporation, Kanagawa) with the digital color matrix camera COOL 1300 (VDS, Vosskűhler, Germany). Immunopositivity was analyzed by the software LUCIA DI image Analysis System LIM (Laboratory imaging Ltd., Prague, Czech Republic) in at least 1,000 cells per sample. In all experiments, the system of immunological control was employed to avoid false positive or negative staining reactions.

\section{Statistics}

Statistical analysis was carried out with a statistical program GraphPad Prism (GraphPad Software, inc. San Diego, U.S.A.). We used one-way Anova test with Dunnett's post test for multiple comparisons. Results were compared with control samples, and means were considered significant if $\mathrm{P}<0.05$.

\section{Results}

\section{Effect of Zn on morphology of Hep-2 cells}

During $12 \mathrm{~h}$ of exposure to $300 \mu \mathrm{M} \mathrm{ZnSO}_{4}$, various morphological changes were observed in model Hep-2 
cells. In the interval of 2 to $4 \mathrm{~h}$ of treatment, cells gradually developed numerous vacuoles in their cytoplasm. Over next $2 \mathrm{~h}$, individual vacuoles fused into larger bodies and cells started to lose their adherence (Fig. 1B). At 8 to $12 \mathrm{~h}$ of treatment, cells asynchronously detached from the substratum and some showed various surface protrusions resembling blebs (Fig. 1C). Dynamics of individual blebs was very heterogeneous but their formation on the cell surface was invariably random and the entire process lasted only a few minutes. In addition, in all detached cells, violent internal movements were visible which were independent of any surface changes. Nuclear changes were not observable during the first $\mathrm{h}$ of treatment and the nucleus retained its integrity even during cell rounding. The nuclear collapse characterized by rapid shrinkage followed by regional swelling occurred in the late periods of the treatment ( 10 to $12 \mathrm{~h}$ ).
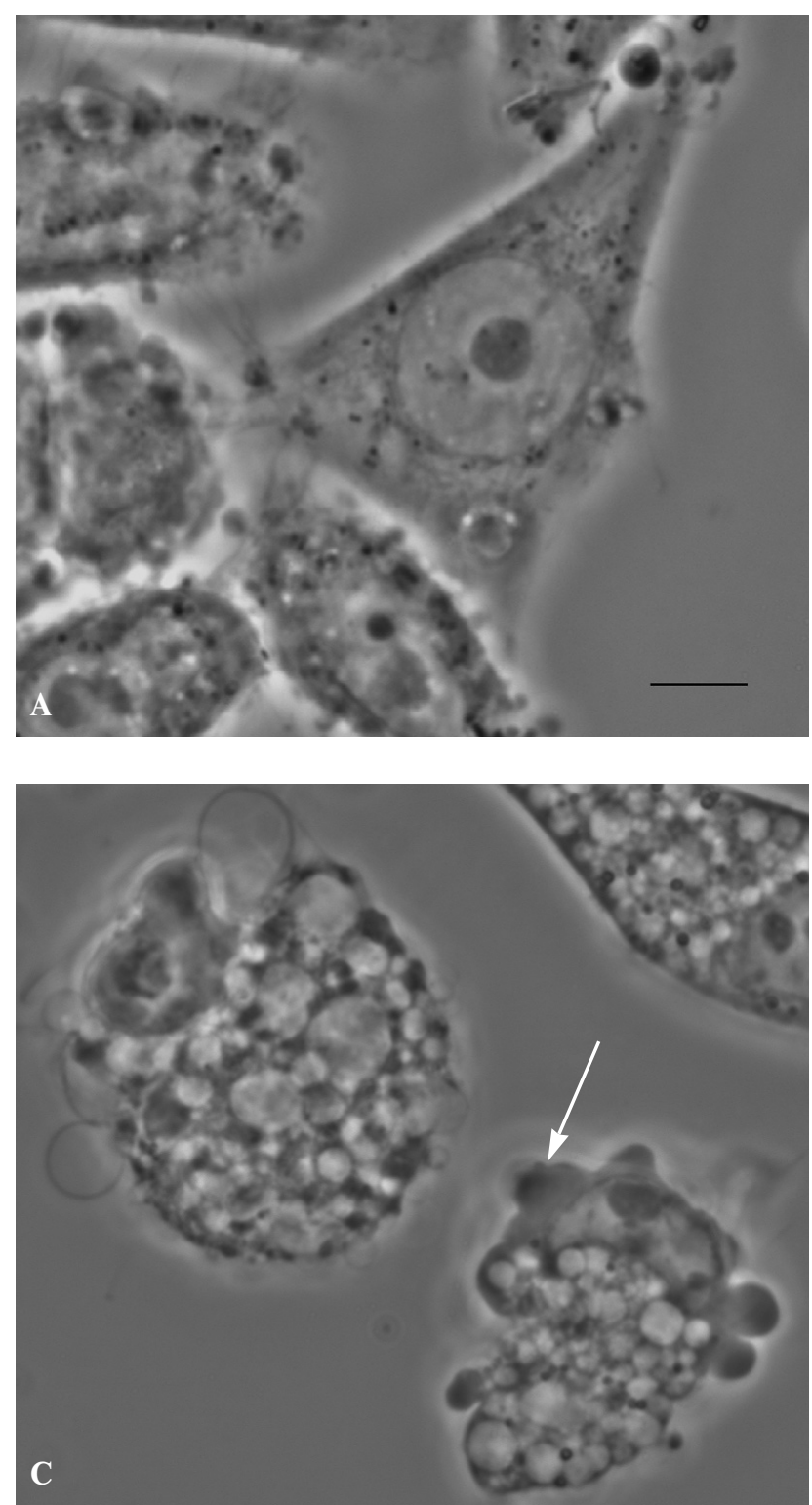

\section{Effect of $Z n$ on actin cytoskeleton of Hep-2 cells}

Fig. 2 shows the organization of the actin cytoskeleton in Hep-2 cells treated with $\mathrm{Zn}$ for $8 \mathrm{~h}$. F-actin cables aggregated on the cell surface and at the subcortical regions of the observed cells, often forming focal clumps or other irregular bodies. In contrast to control cells where G-actin localized not only in the cells' bodies but especially at the periphery, in treated cells it concentrated to the central part of the cells and retracted from the periphery. Membrane protrusions-blebs while being positive for F-actin stained very weakly for G-actin. When exposed to $\mathrm{Zn}$ and co treated with myosin light chain kinase inhibitor ML-7 and ROCK I kinase inhibitor Y 27632, Hep-2 cells showed no difference in their F- and G-actin rearrangement (Fig. 2C).

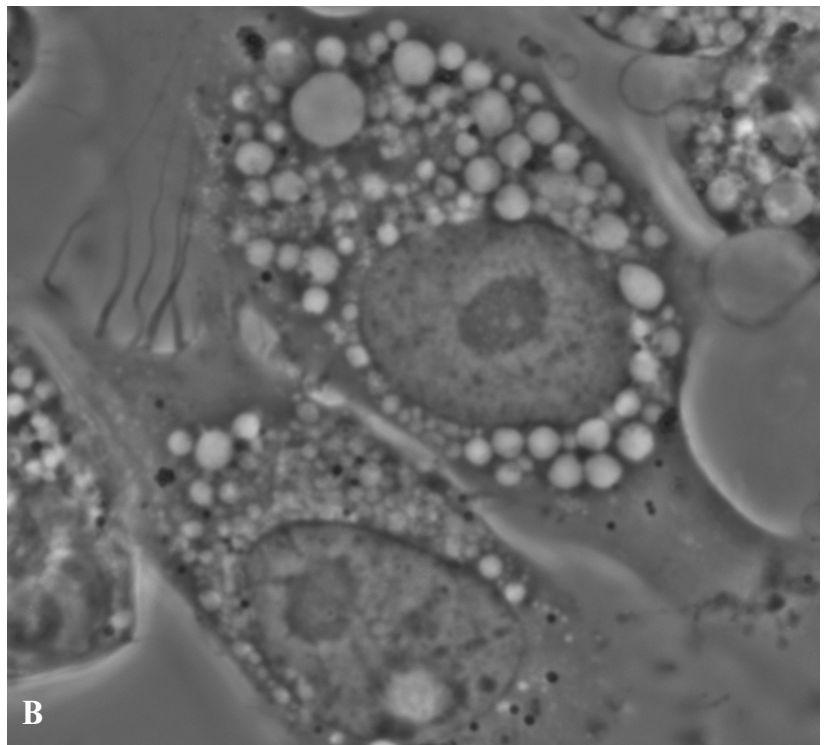

Fig. 1: Morphological appearance of Hep-2 cells treated with $300 \mu \mathrm{M}$ zinc during 12h. (A) control cells (B) cells at $4 \mathrm{~h}$ of treatment, there is marked development of extensive vacuolization and loss of adherence $(\mathrm{C})$ cells at $8 \mathrm{~h}$ of treatment - it is visible specific blebbing (arrow). Phase contrast 1000x. Bar $10 \mu \mathrm{m}$. 
F-actin
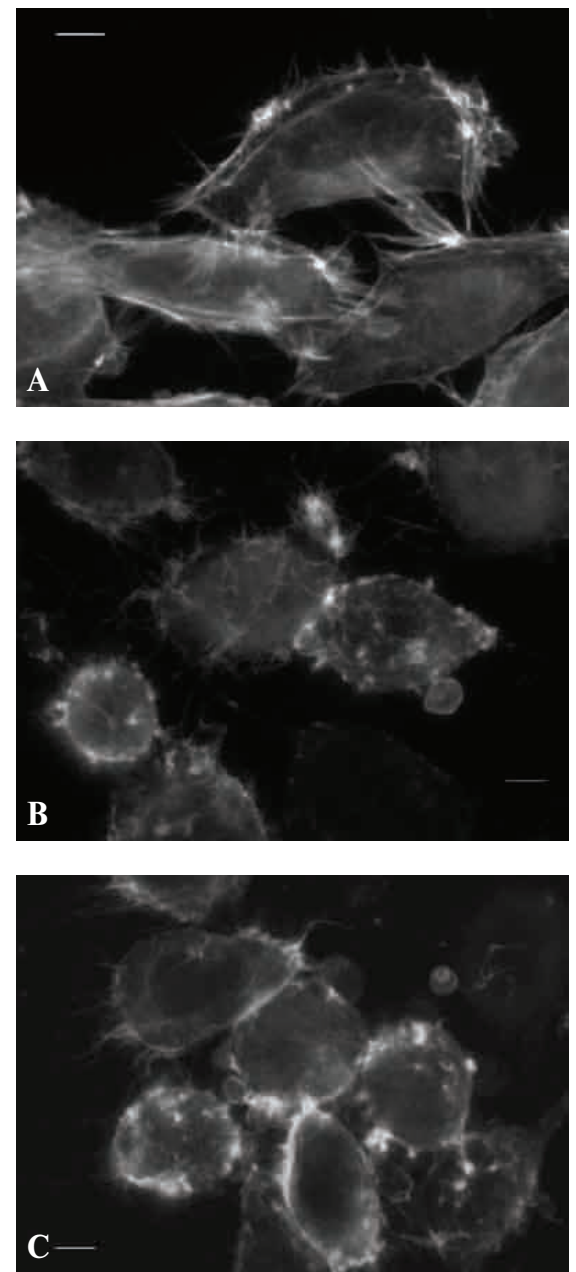

G-actin
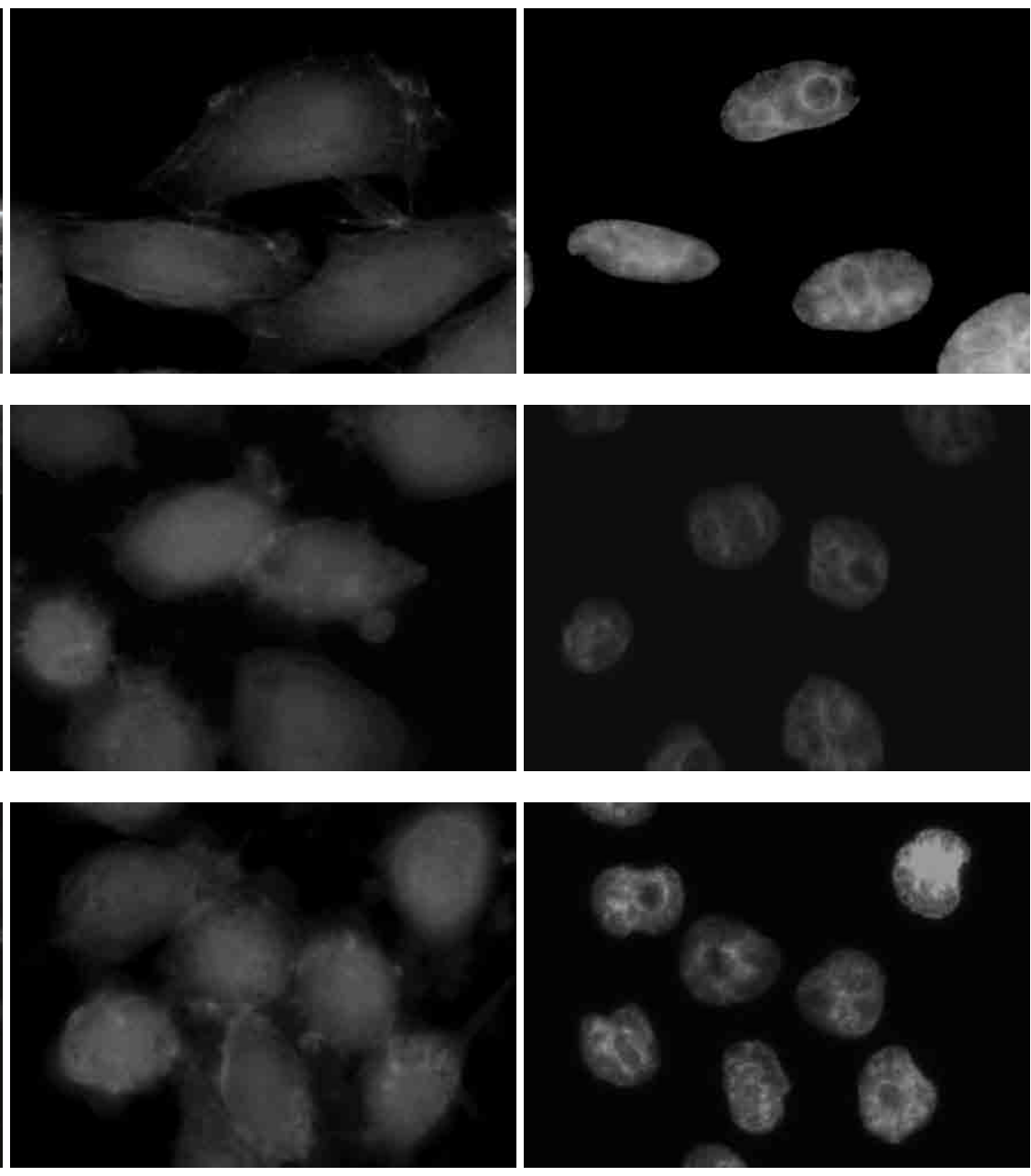

Fig. 2: Cytoskeletal changes in Hep-2 cells treated with $300 \mu \mathrm{M}$ zinc during $12 \mathrm{~h}$. (A) control cells (B) cells at $8 \mathrm{~h}$ of treatment $(\mathrm{C})$ cells at $8 \mathrm{~h}$ of treatment with co-administration of myosin light chain kinase inhibitor ML-7 and ROCK I kinase inhibitor Y 27632. Fluorescence 600x, BAR $5 \mu \mathrm{m}$.
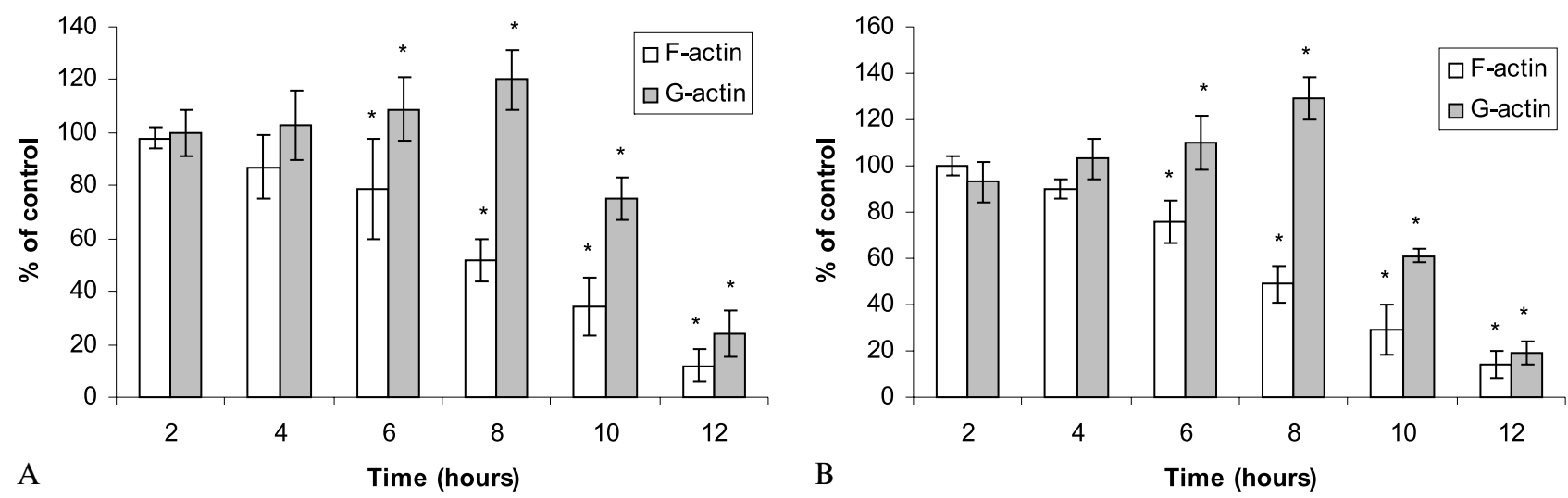

Fig. 3: Effect of $\mathrm{Zn}(300 \mu \mathrm{M})$ on F- and G-actin levels of Hep-2 cells during 12h. Analysis was carried out by fluorimetric microplate assay. (A) Normal treatment conditions, (B) with co-administration of $50 \mu \mathrm{M}$ pan caspase inhibitor z-VADfmk. Values represent the mean $\pm \mathrm{SD}$ of three different experiments. ${ }^{*} \mathrm{P}<0.05$ with one way-Anova test and Dunnett's post test for multiple comparisons. 


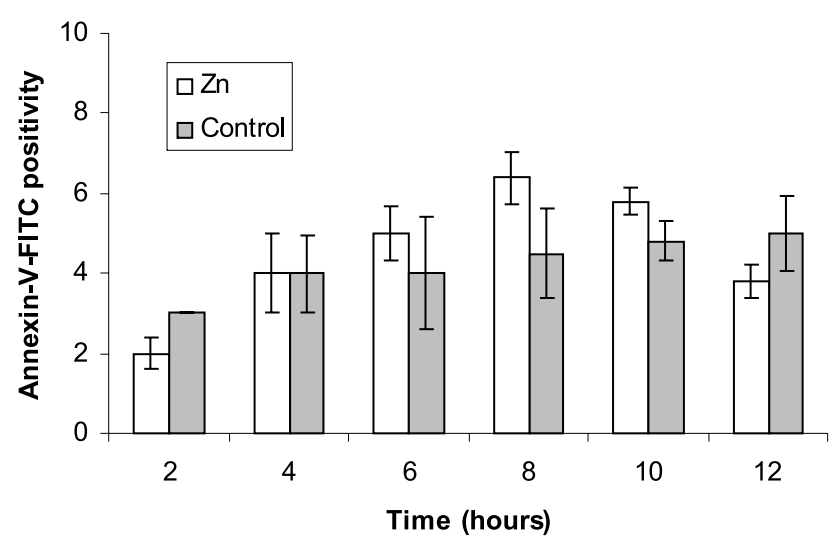

Fig. 4: Phosphatidyl serine externalization measured by specific Annexin-V-FITC staining in $\mathrm{Zn}$ treated Hep-2 cells. Values represent the mean \pm SD of three independent experiments.
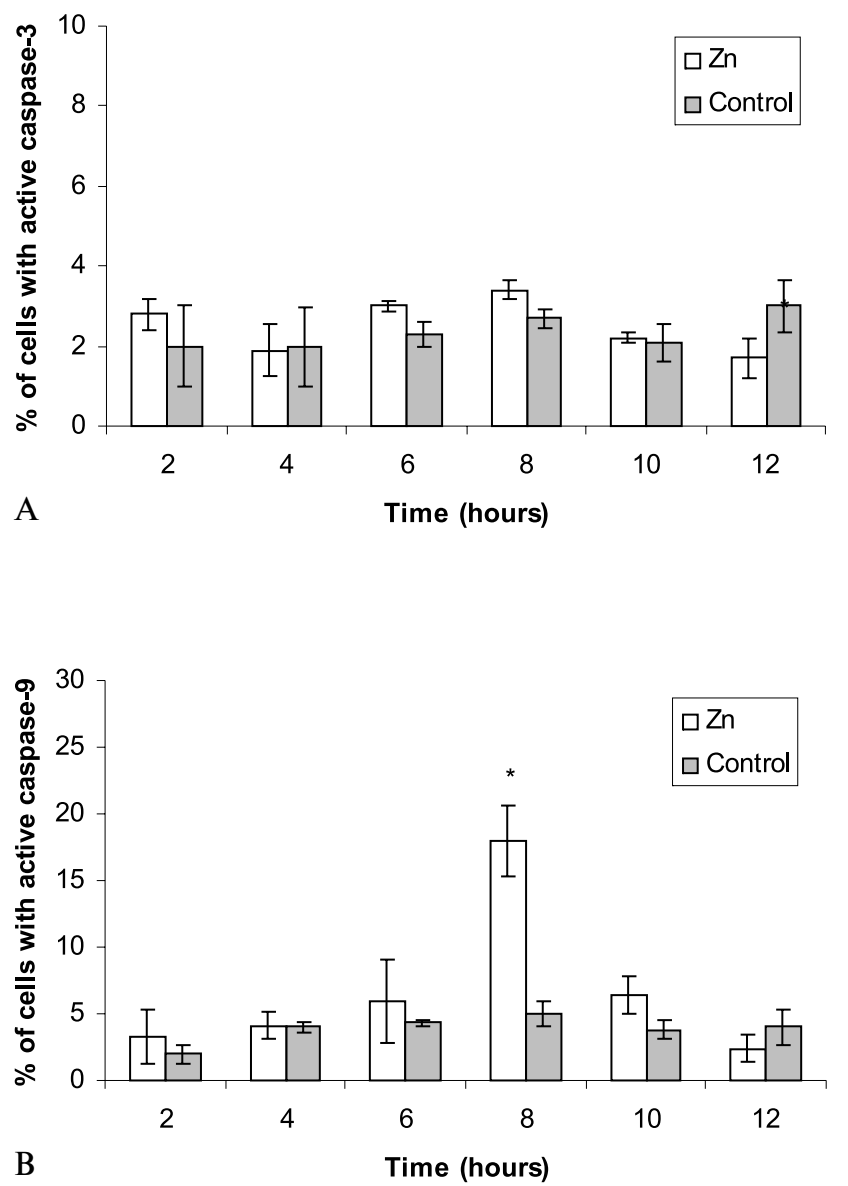

Fig. 5: Activation of caspases in $\mathrm{Zn}$ treated Hep-2 cells. (A) caspase-3 (B) caspase-9. Values represent the mean \pm SD of three independent experiments. ${ }^{*} \mathrm{P}<0.05$ significantly different from control with one way-Anova test and Dunnet's post test for multiple comparisons.

\section{Changes in $F$-and $G$-actin content in treated \\ Hep-2 cells}

In order to determine the effect of $\mathrm{Zn}$ on disruption of actin cytoskeleton of cancer Hep- 2 cells, we measured Fand G-actin levels during $12 \mathrm{~h}$ incubation with $300 \mu \mathrm{M}$ $\mathrm{ZnSO}_{4}$. Fig. 3 illustrates that F-actin pools significantly decreased during $12 \mathrm{~h}$ lasting exposure while G-actin initially showed an increase which was followed at $8 \mathrm{~h}$ of treatment by a rapid decline. Activated caspases, in particular caspase-3, have been identified to be responsible for specific cleavage of cytoskeletal proteins in programmed cell death. To verify their involvement in the studied cell death process, we used pan caspase inhibitor Z-VAD-fmk. Fig. 3B clearly shows that no differences in actin content in thus dying cells were evident after administration of the above mentioned pharmacological inhibitor.

\section{Zn-induced cell death involves neither phosphatidyl serine translocation nor caspase activation}

Phosphatidyl serine (PS) exposure at the surface of dying cells as well as the specific activation of caspases are almost universal features of programmed cell death - apoptosis. To test whether they are present in $\mathrm{Zn}$-induced cell death in Hep-2 cells, we carried out immunofluorescent detection of both initiator (caspase-9) and executionary (caspase-3) activated caspases along with the specific detection of PS during 12h of treatment. During the entire course of treatment, the presence of PS in the cell membrane of cultures was not significantly different from control cells (Fig. 4). Interestingly, although caspase-9 was transiently increased in treated cells (approximately between 8 and $9 \mathrm{~h}$ of treatment) there were no signs of activation of caspase- 3 in the same cells (Fig. 5).

\section{Discussion}

Morphological as well as molecular changes in apoptotic cells are nowadays known in a great detail owing to the incessant interest and huge efforts of many scientists over past years. These studies led not only to elucidation of many details in apoptotic signaling pathways but also revealed many circumstances when cells die while deviating (morphologically or molecularly) from the classical concept of apoptosis or necrosis. Thus there have been reported other types of cell death named autophagy, nonlysosomal vesiculate degradation, necroptosis or aponecrosis $(3,4)$. Furthermore, recent reports suggest that even necrosis might represent a type of programmed cell death with a specific role in the organism such as elimination of apoptosisresistant tumor cells $(7,8)$. While these studies continue in deciphering details about molecular background of such unusual types of cell death, very little efforts are being paid to the detailed morphological analysis of these cells.

In our present study we wanted to characterize nonapoptotic cell death in model adherent cancerous Hep-2 cells treated with $\mathrm{Zn}$. $\mathrm{Zn}$ is a widely studied microelement 
which has many significant functions in eukaryotic cells (10). On the other hand, at higher concentrations it has been linked with toxicity and induced cell death, both apoptosis and necrosis $(5,14)$. Based on our previous studies where we have shown that $\mathrm{Zn}$ is capable of inducing apoptosis or necrosis in relation to the concentration used (12), we wanted to verify our hypothesis about intermediate type of cell death as a possible linkage between two opposite ends - apoptosis and necrosis. Moreover, we wanted to investigate morphology of such a death and its underlying causes. Therefore, we treated Hep-2 cells with $300 \mu \mathrm{M} \mathrm{Zn}$, a concentration just between apoptosis causing $150 \mu \mathrm{M}$ and necrosis stimulating $500 \mu \mathrm{M}$, and observed cell behavior and morphology during $12 \mathrm{~h}$.

Our results show that upon a given exposure, Hep-2 cells develop some characteristic features attributed to necrosis including an extensive cytoplasmic vacuolization, random and fast nuclear shrinkage and missing activation of caspases. This observation seems also to be supported by consistent, random looking degradation of actin cytoskeleton (Fig. 4). On the other hand, observed blebbing in some treated cells as well as their internal activity were not consistent with the concept of necrosis. Membrane blebbing is one of the most characteristic features of apoptotic cell death where formation of dynamic membrane protrusions is mediated by the specific cleavage and contraction of actomyosin complex in the presence of caspase-activated Rho kinases $(1,13)$. To confirm our phase contrast observations, we stained treated cells for F- and G-actin in the presence or absence of Rho kinase or caspase inhibitors. We discovered that surface protrusions-blebs formed on the surface of dying cells are positive for F-actin but only weakly positive for G-actin (Fig. 2). Furthermore, neither of two employed inhibitors had any effect on the occurrence and/ or timing of blebbing. Also, the absence of phosphatidyl serine on the external face of the cell membrane suggested a non-apoptotic mechanism. These results allowed us to conclude that cytoskeletal degradation and characteristic membrane behavior in this model resulted from some other, probably caspase-independent mechanism.

To investigate this idea, we detected in the treated cells the presence of activated caspase- 9 and -3 . Surprisingly, we found a significantly increased expression of the active caspase- 9 at $8 \mathrm{~h}$ of treatment but no activation of caspase- 3 at any time intervals. There can be several explanations for this discrepancy. Firstly, regarding multiple targets of $\mathrm{Zn}$ in the cell, it is possible that caspase- 9 was activated only incidentally. This would explain its transient nature and the fact that it took place rather late when other changes already took place. Secondly, it is possible that this activation has been scheduled but the continuing process was switched or reverted at some point downstream, thereby changing the type of cell death as it has been observed at other experimental systems. Activation of caspase- 3 could represent here a crucial point as it has been shown that this process is inhibited in the presence of $\mathrm{Zn}$ ions (6).

\section{Conclusion}

Hep-2 cells treated with $300 \mu \mathrm{M} \mathrm{ZnSO}_{4}$ during $12 \mathrm{~h}$ develop extensive vacuolization followed by the specific degradation of actin cytoskeleton and in some cases by membrane blebbing. Both cytoskeletal damage as well as membrane changes occur in a distinct way and differ from the ones seen in apoptosis. A sequence of fragmentation processes might initially involve caspase-9 but later appears to occur by a caspase-independent mechanism. These observations suggest the presence of a special type of cell death combining features of apoptosis, necrosis, and possibly some other types such as autophagy.

\section{Acknowledgement}

This work was supported by Ministry of Education Research Project MSM 0021620820.

\section{References}

1. Coleman ML, Olson MF. Rho GTPase signalling pathways in the morphological changes associated with apoptosis. Cell Death Differ 2002;9:493-504.

2. Danial NN, Korsmeyer SJ. Cell death: critical control points. Cell 2004; 116:205-19.

3. Edinger AL, Thompson CB. Death by design: apoptosis, necrosis and autophagy. Curr Opin Cell Biol 2004;16:663-9.

4. Fiers W, Beyaert R, Declercq W, Vandenabeele P. More than one way to die apoptosis, necrosis and reactive oxygen damage. Oncogene 1999;18:7719-30.

5. Haase H, Watjen W, Beyersmann D. Zinc induces apoptosis that can be suppressed by lanthanum in C6 rat glioma cells. Biol Chem 2001;382:1227-34.

6. Chai F, Truong-Tran AQ, Evdokiou A, Young GP, Zalewski PD. Intracellular zinc depletion induces caspase activation and $\mathrm{p} 21$ Wafl/Cip1 cleavage in human epithelial cell lines. J Infect Dis 2000;182 Suppl 1:S85-92.

7. Chan FK, Shisler J, Bixby JG, Felices M, Zheng L, Appel M, Orenstein J, Moss B, Lenardo MJ. A role for tumor necrosis factor receptor-2 and receptor-interacting protein in programmed necrosis and antiviral responses. J Biol Chem 2003;278:51613-21.

8. Jaattela M, Tschopp J. Caspase-independent cell death in T lymphocytes. Nat Immunol 2003;4:416-23.

9. Papucci L, Formigli L, Schiavone N, Tani A, Donnini M, Lapucci A, Perna F, Tempestini A, Witort E, Morganti M, Nosi D, Orlandini GE, Zecchi Orlandini S, S. C. Apoptosis shifts to necrosis via intermediate types of cell death by a mechanism depending on c- myc and bcl-2 expression. Cell and Tissue Research 2004;

10. Prasad AS. Zinc and immunity. Mol Cell Biochem 1998;188:63-9.

11. Proskuryakov SY, Konoplyannikov AG, Gabai VL. Necrosis: a specific form of programmed cell death? Exp Cell Res 2003;283:1-16.

12. Rudolf E, Rudolf K, Radocha J, Peychl J, Cervinka M. The role of intracellular zinc in modulation of life and death of Hep-2 cells. Biometals 2003:16:295-309.

13. Sebbagh M, Renvoize C, Hamelin J, Riche N, Bertoglio J, Breard J. Caspase-3mediated cleavage of ROCK I induces MLC phosphorylation and apoptotic membrane blebbing. Nat Cell Biol 2001;3:346-52.

14. Takeda A. Movement of zinc and its functional significance in the brain. Brain Res Brain Res Rev 2000;34:137-48.

Submitted February 2006.

Accepted April 2006.

Doc. PharmDr. Emil Rudolf, Ph.D., Charles University in Prague, Faculty of Medicine in Hradec Králové, Department of Medical Biology and Genetics, Šimkova 870, 50038 Hradec Králové, Czech Republic. email: rudolf@lfhk.cuni.cz 